\title{
Chapter 2 \\ Central Bank Policy Mix: Issues, Challenges, and Policy Responses
}

\author{
Solikin M. Juhro
}

\begin{abstract}
In the aftermath of the Global Financial Crisis, conventional economic policies have been considered insufficient in stabilizing the domestic economy. The new global economic conjuncture necessitates a modification in the existing policy framework by enhancing it with other policies; such as macro prudential policy, exchange rate policy, capital flow management, monetary and fiscal policy coordination as well as structural adjustments. This is now referred to as the policy mix.
\end{abstract}

Keywords Central bank policy $\cdot$ Policy mix $\cdot$ Global financial crisis $\cdot$ GFC $\cdot$ Policy response

\section{Introduction ${ }^{1}$}

I would like to welcome all the participants. Welcome to Jakarta, the capital city of the Republic of Indonesia. It is an honor for me to welcome you to the international workshop entitled "Central Bank Policy Mix: Issues, Challenges and Policy Responses". I would like to deliver three issues that will anchor the next few days. First, I would like to explain why the BI Institute organized this workshop on the theme of the central bank policy mix. Second, the essence of central bank policy mix formulation, which represents the backbone of the future central bank policy strategy in facing the global uncertainties that are expected to heighten with the emergence of the new digital era. Third, the outcomes we expect to deliver from this international flagship program.

\footnotetext{
${ }^{1}$ Since 2015, BI Institute of Bank Indonesia hosts the annual international flagship workshop and seminar entitled "Central Bank Policy Mix: Issues, Challenges and Policy Responses". The workshop and seminar is intended to explore insights from prominent experts on empirical and practical experiences in conducting central bank policy mix, with participants coming from middle-to-senior level officials from overseas central banks, domestic regulatory agencies and academics.
}

S. M. Juhro $(\bowtie)$

Bank Indonesia, Jakarta, Indonesia 
This event, created and hosted by the Bank Indonesia Institute of Bank Indonesia, in conjunction with the International Monetary Fund-Singapore Training Institute (IMF-STI), the Central Bank of the Republic of Turkey (CBRT), and the Reserve Bank of India (RBI), is held annually with the same theme. The first event was held in 2015 in collaboration with the ECB but in the next following years we have been working with our strategic partners, including the IMF-STI, central bank partners (CBRT and RBI), and other prominent institutions. Our target audience for this course consists of mid- to senior-level officials working in macroeconomics, the financial sector and fiscal sector from the central bank and other public institutions. For Bank Indonesia, this course has been an integral part of our international flagship program. Every year, we have around 15 international flagship programs, in terms of workshops and seminars, including a research conference because we manage two international journals, namely the Bulletin of Monetary Economics and Banking, indexed by Scopus, as well as the Journal of Islamic Economics and Banking. I invite you all to submit your research articles to our journals.

These events are co-hosted by various leading institutions as part of Bank Indonesia Institute's journey towards becoming a world-class learning and research institution. This year, we are holding 15 international workshops and seminars. This is our fifth flagship event this year with many more still to run. For sure, we can add many other strong visions to the long list of why collaboration on the knowledge advancement in this field through such workshops is essential for the preparation of anticipating future potential challenges, crises even, in order to ensure long-term economic stability and prosperity.

The key messages I will explore briefly in my remarks, with regard to the central bank policy mix, are based on important issues that need to be tackled by central banks and other public institutions in a well-measured approach. The world situation under global hyper-connectedness, a higher degree of openness and increasing speed of contagious spillover effects from country to country, and region to region, need the timely and relevant issues to be addressed. This is to become more relevant when we are dealing with the challenges ahead in managing the emergence of the digital economy and the advancement of technological progress. The global economy in the aftermath of the Global Financial Crisis in 2008/09 (GFC) was remarkable. It was the worst financial crisis since the Great Depression of the 1930s. The scope and severity of the crisis were global and exceptional and forced policymakers to take some unconventional policy measures. The financial crisis was unprecedented and the impact has been prolonged as the global economic landscape enters a new norm, with a lower growth trend and more volatile financial markets. Since then, volatility, uncertainty, complexity and ambiguity (VUCA) have re-emerged in the global economic discourse. Now, we are facing not only VUCA but also TUNA. After the situation escalated through trade tensions and retaliatory actions between the US and several other countries, the geopolitical situation in some regions, and escalation of the capital flows from emerging markets globally, we are now familiar with the economic terminology TUNA (turbulence, uncertainty, novelty and ambiguity). 


\section{Financial Crisis and Central Bank Policy Challenges}

The understanding of the sources of a crisis is very important as what happened to the Asian economy 1998 that was hampered by the Asian Financial Crisis of 1997/98 and the global economy that was melted by the GFC. The crises and their aftermath have been painful reminders of the multifaceted nature of crises, either a currency crisis, debt crisis or banking crisis. We have also learned from the latest financial crisis that favorable global economic conditions, such as the Great Moderation during the period of decreasing macroeconomic volatility, as experienced in the United States and other advanced economies, could alert policymakers to misleadingly follow procyclical economic and financial policies. We saw that in the early 1990s, even the Great Moderation could not guarantee that the global economy could be isolated from the crisis because in 2008 we saw that the authorities lack of identifying the sources of crisis, stemming from the vulnerability to the financial crisis, led to the global financial crisis and the prolonged impact that we are feeling to this day.

The global crisis showed that maintaining price stability without maintaining financial system stability is not enough to achieve macroeconomic stability. There is no macro stability without financial stability. The dynamics of capital flows quickly affect the effectiveness of monetary policy, therefore the monetary authority must use a variety of instruments, hence developing from a normal situation where the central bank respond to inflation and the fiscal authorities respond to finance public expenditures. In the aftermath of the GFC, the conventional economic policies were considered no longer sufficient in terms of stabilizing the domestic economy. Several central banks being aware of the condition that new global economic conjuncture necessitates a modification in the existing policy framework by enhancing other policies, such as macroprudential policy, exchange rate policy, capital flow management, fiscal policy coordination and structural adjustments. This is now referred to as the policy mix (Warjiyo and Juhro 2016, 2019). Of course, from an academic point of view, we acknowledge that there have been some thoughts about various formats of ITF implementation, from standard ITF to flexible ITF and integrated ITF, which underlie this policy mix format. This approach is basically preserving the main objective of achieving and maintaining price stability, while safeguarding financial stability as the supporting or secondary objective.

With the emergence of widespread global uncertainty, the primary goal of monetary policy is to strike the right balance between mitigating the downward pressures on domestic economic growth arising from the global economic downturn, while ensuring stability in the medium-term. As central bankers, almost all of us well understand of the nature of the Mundell-Fleming: Impossible Trinity concept based on seminal works of Mundell in 1968 (Fleming 1962; Mundell 1963). The Policy Trilemma, where over time, the three goals cannot be attained simultaneously and only two out of three conditions can be applied together, is very well-known in the literature for a small open economy. The "Impossible Trinity" actually indicates that the dream of any central bank to have free capital mobility, stable exchange rates and 
independent monetary policy, which are hard to achieve in the "corner solutions". Our speakers today will provide more details on these issues.

We are living in an imperfect world, so greater domestic economic integration with the global economy, coupled with intense foreign capital flows and exchange rate dynamics, has increased the complexity of monetary management. To confront these issues, the choice of monetary policy strategy has become how to transform the impossible trinity into a possible trinity. The concept of a possible trinity can be expressed as an intermediate solution for a small open economy, including Indonesia that avoids volatile swings in the exchange rate, controls excessive short-term capital inflows and reinforces autonomous monetary policy. In this regard, for the case of Indonesia, to manage the monetary stability framework is indeed to manage the monetary policy trilemma, namely simultaneously achieving the three intermediate goals depending on the central bank's preference in terms of three conditions (Juhro 2015; Juhro and Goeltom 2015).

First, maintaining monetary policy autonomy in achieving price stability by utilizing a monetary and macroprudential policy (instrument) mix. Under standard ITF, we assume a flexible exchange rate regime but the underlying assumption does not hold mostly, for instance uncovered interest parity and the domination of imprudent foreign borrowing in domestic debt. The fact that exchange rate movements are mostly driven by market perception rather than demand and supply, we cannot rely on the free exchange rate assumption. That is why, under ITF, we cannot just rely on the interest rate as our instrument. To maintain monetary policy autonomy, we need another instrument from a macroprudential perspective.

The second condition is stabilizing exchange rate movements in line with the currency's fundamental value by employing exchange rate management. From Bank Indonesia's perspective, we have the perception that the exchange rate should be in line with its fundamental value. Therefore, if our balance of payments is performing well and our current account deficit is narrowing, we will automatically have a stronger exchange rate. In the short term, we have to smooth the volatility by engaging in a floating exchange rate regime. All central banks engage in some form of intervention.

Third, managing capital flow dynamics to support macroeconomic stability by implementing capital flow management. Our resource person in this program will hopefully explain about capital flow management, why we cannot just open our economies. We have included capital flow management in terms of financial system stability as a temporary action not a permanent action. The coordinated implementation of a policy instrument mix is ultimately part of an important strategy to manage the monetary policy trilemma in the current climate blighted by high uncertainty. Coordination is critical, not only to address sources of external and internal imbalances, but also to optimally manage the impact of monetary policy, while avoiding overkill and mutual exclusivity. Within that policy perspective, the achievement of macroeconomic stability is not only tied to monetary stability (price stability) but also to financial system stability. 


\section{From ITF to Policy Mix}

Under ITF-based monetary policy, which was formally adopted by Bank Indonesia in July 2005, the main priority of Bank Indonesia is to build central bank policy credibility. Therefore, it can only be expected that consistent commitment and determined implementation will be essential to the realization of a more credible ITF. Despite progress having been made since the crisis, the economy is still burdened by various constraints and problems. In this regard, the challenge in monetary policy is to contain rising inflationary pressures without impeding economic growth. We see that Indonesia is now growing at around 5\% but we have grown by as much as $6.8 \%$ in the past. In the post-GFC and Asian financial crisis period, we are facing a new norm, with growth at around 5\%. Under the new norm, 5\% is very impressive, however, only below China and India. The question is whether or not a monetary policy framework aimed at achieving price stability is still relevant, such as ITF. The answer is a resounding "Yes".

In his article, even Frederick Mishkin mentioned that crises do not undermine the basic principles of monetary policy, such as the importance of price stability, time consistency, independence and accountability of monetary policy and so on (Mishkin 1999). These are not disrupted by a crisis. We still need these assumptions in order to maintain ITF credibility. The fundamentals of ITF are not hampered by a crisis. We feel that ITF is still relevant. Although Bank Indonesia still sees ITF as a reliable monetary policy strategy for Indonesia, the framework needs to be enhanced by refining future ITF implementation strategy.

From a Bank Indonesia policy perspective, we see that ITF is still relevant but we need more flexibility in ITF implementation. Consequently, Bank Indonesia has enhanced ITF implementation under the unconventional wisdom of monetary policy, which later became the embrio of central bank policy mix (Juhro 2015; Juhro and Goeltom 2015; Warjiyo and Juhro 2016, 2019). There are five aspects of enhancement. First, continuing the adherence of the policy framework to an inflation target as the overriding objective of monetary policy. In this case, the main characteristics of ITF will remain, for example pre-emptive, independent, transparent and accountable policy implementation. Second, integrating monetary and macroprudential policy instruments. Appropriate monetary and macroprudential policy integration is required in order to buttress monetary and financial system stability. Third, managing the dynamics of capital flows and exchange rates. In supporting macroeconomic stability, coordinated implementation of a policy instrument mix must ultimately be part of an important strategy for optimally managing the monetary policy trilemma as I explained previously.

Two other aspects related to institutional strengtening, namely communication strategy and coordination. Communication strategy is not just for the sake of transparency and accountability. We regard good policy communication as an effective monetary policy instrument. There is a lot of evidence in Indonesia that when our central bank governor or members of the board of governors provide a strong and 
clear message to the market, it helps influence how market players behave and stabilizes the market. This reduces our intervention costs. Last aspect is strengthening Bank Indonesia and government policy coordination. Policy coordination is crucial, given that inflation stemming from the supply side creates most inflation volatility. We are currently facing a flattening of the Phillips curve. This implies that the supply side is playing a more important role in terms of inflationary pressures. Therefore, we have to strengthen policy coordination in terms of monetary policy. Indeed, we have put strong synergy and coordination across a broader area through structural reforms in order to effectively balance between pro-stability and pro-growth strategies.

Therefore, under (enhanced) Flexible ITF, feasibility in policy mix implementation can be achieved through, amongst others, additional macroprudential instruments in addition to monetary instruments, which should reinforce one another. While monetary instruments will be utilized to influence monetary variables, such as interest rates, exchange rates, credit and expectations, macroprudential instruments will be utilized mainly to manage risk potential or perception in the financial markets. Fundamentally, the central bank policy mix represents the optimal integration of monetary policy, macroprudential policy and managing capital flows and exchange rates.

Now, we are moving to integrated ITF. The terminology has a broader scope than the flexible ITF proposed in several studies, such as Agenor and da Silva (2013). This represents the academic backbone of integrated ITF. Bank Indonesia has already crystalized these similar thoughts about the policy mix since 2010 but "unfortunately", we did not publish our findings. We have internal documentation concerning similar research into integrated ITF.

There are three salient characteristics of integrated ITF. First, and departing from conventional flexible ITF, the ultimate target is not only price stability but also maintaining financial system stability. Under flexible ITF, we are just integrating the function of the target, integrating the policy strategy, not only to maintain monetary policy stability but also financial system stability. Nonetheless, we do not talk about the mandate. Integrated ITF is more concrete. The ultimate target is not only price stability but also maintaining financial system stability. We have a dual mandate, which could be two primary mandates or a primary and secondary mandate. This is one of the issues we can discuss. Second, and similar to flexible ITF, the instruments used are monetary policy, macroprudential policy and foreign capital flow management in one optimal mix. If you read the e-books, they have more concrete policy rules. This basically strengthens flexible ITF. Third, which is also like flexible ITF, policy mix formulation requires an analysis framework and macroeconomic projections that take into consideration macro-financial linkages.

Therefore, integrated ITF poses the theoretical backbone for the implementation of the central bank policy mix. In central bank policy mix implementation, three salient aspects demand attention, namely: (i) how the dual targets of price stability and financial system stability can be integrated; (ii) the mix of policy instruments to use; and (iii) the effectiveness of the transmission mechanism. This is the subject of the research because these are frontier ideas that require further elaboration through future research. 
The description in the upper part explains how price stability and financial system stability can be integrated into the dual mandate of the central bank. In Indonesia, for the case of Bank Indonesia, the authorities in charge of financial system stability are not just the central bank or the Indonesian Financial Services Authority (OJK) but also the Deposit Insurance Corporation (LPS) and Ministry of Finance, which all come together under the auspices of the National Financial System Stability Committee. We share the responsibility for financial system stability. That is why the main mandate of Bank Indonesia is to maintain and achieve currency stability, including inflation and exchange rate stability. To achieve financial system stability, our perspective is to support maintaining price stability because there are four authorities that have the same responsibility to guide financial system stability.

\section{Salient Policy Responses: Pro-stability and Pro-growth}

Let me share Indonesia's economic journey in 2018-2019 and describe Bank Indonesia's policy mix. We experienced a long journey last year which provides three important lessons to strengthen synergy in order to enhance resilience and encourage economic growth amidst global economic conditions that remain unfavorable. From our perspective, we have put two strategies into the central bank policy mix. We still hold our mandate to maintain stability but facing the global uncertainty that has impacted lower potential economic growth, the strategy depends on the preferences of the central bank. The central bank's main preferences are inflation deviation and output deviation; the rest is just about preference. Therefore, pro-stability and pro-growth are our strategy in 2019.

To maintain price stability, Bank Indonesia will preserve a pre-emptive and aheadof-the-curve monetary policy stance in 2019. For this reason, several salient policy responses are to be done. First, the interest rate policy will continue to be directed to ensure that inflation is under control to achieve its target, namely $3.5 \% \pm 1 \%$ in 2019 and $3.0 \% \pm 1 \%$ in 2020 . This is our disinflation path from $6.0 \% \pm 1 \%$ just a few years ago. This clearly demonstrates the performance of the ITF regime we adopted in 2005 in terms of bringing down stable inflation. Second, the market mechanism for maintaining rupiah exchange rate stability continues to be encouraged, without reducing the need for intervention. We have created a balance. Of course, we need market mechanisms as our basic guidance to preserve a flexible exchange rate regime but when we see potential volatility that will cheat the market expectations, we intervene as a last resort. Third, adequacy of foreign exchange reserves will continue to be maintained. Fourth, adequacy of liquidity in the money market and banking industry will also be maintained.

If we talk about traditional medicine, Jamu, we see that there is bitter medicine and sweet medicine. So, we put it in a more balanced strategy. To build economic growth momentum, Bank Indonesia applies macroprudential policies, payment system policies, financial market deepening and development of Islamic economy and finance. I do not want to elaborate in more detail because we will present the Indonesian case 
on the third day as shared by our colleagues from Bank Indonesia. Basically, this is a representation of how Bank Indonesia articulates its way to implement the policy mix strategy. Behind the strategy, there will of course be rigorous work done by our departments in terms of monetary policy and macroprudential policy. They have a modelling structure, policy rules and other discussions and policymaking decisions. Frontier research is used to back up sound policy.

\section{Challenges Ahead}

In the last part, I would like to share my view about the challenges ahead in terms of managing the emergence of the digital economy and technological advancement. Amidst all the global and domestic challenges due to the widespread impact of the AFC and the GFC, it is also important to understand potential new crises if the digital economy uprising is not managed properly. Even the cause of GCF, 10 years ago, was based on the real sector, especially property, but the exposure to unanticipated financial derivatives, such as risky subprime mortgage securities and a lack of prudential financial sector regulation, were the contributory factors of the crisis. We have to be aware of progress of new technology. Hence, we have to anticipate the next future challenges, such as the massive emergence of new forms of financial intermediation and the risk exposures following the exponential growth of shadow banking and financial technology (FinTech) development. The massive advance of technological aspects in delivering financial transactions and other digital economic challenges need a 3-A approach according to Mersch (2017), from the European commission. First, adapt policies to take into account technology-driven socio-economic changes. Second, adopt appropriate technology that supports the various functions and tasks of central banks. Third, Anticipate technological risks to operations. Of course, uncontrolled situations will continue to persist and technological advancement will continue to impact monetary policy. There has not been an impact on monetary policy yet but perhaps in the future. Money is growing along with technology, so it will have an impact on how we operate monetary policy. This is important to understand.

In applying the 3-A concept as mentioned earlier, central banks and financial institutions require transformative shifts, including a change of mindset, a measure of interconnected behaviour and integrated policy formulation beyond standard central bank policy wisdom. In that sense, coordination becomes more critical, especially coordination across ministries and agencies to build a digital economic and financial ecosystem. Synergy between central banks and the financial services authorities on digital financial policies is needed when implementing a payment system based on digital financial policies that could encourage better financial intermediation. Besides, establishment of a national committee for the development of digital finance becomes more crucial. Amongst the government ministries and agencies, we are already discussing the need for us to have a formal, integrated national committee for the development of the digital economy and finance. In Indonesia, we are finalizing 
the blueprint for the digital economy and finance. It has not been finalized yet so unfortunately, I am unable to share.

\section{Closing}

This course has succeeded in gathering the brightest minds with experience in both academia and financial practices in the area of the Central Bank Policy Mix. We are lucky that all the issue discussed above will be delivered by a great team, consisting of various experienced senior economists from our strategic partners, including the IMF-STI, RBI, CBRT, Bank Indonesia, and related prominent institutions.

I am convinced we will agree that the challenges faced by the authorities in the macroeconomics area have become more complex over time. Going forward, we really hope that this course will strategically contribute to knowledge-based enhancement in functioning our role as central bankers and the public institution policymakers.

Before I end my remarks, on behalf of Bank Indonesia, I would like to express my sincere gratitude to all strategic partners for a prolonged and wonderful collaboration, distinguished speakers for their willingness to share expertise and knowledge, and the participant for taking time to concentrate and contribute to this enlightening course.

May God Almighty bless and enlighten our steps towards a better future. Please enjoy a fruitful and lively discussion and have a pleasant stay in Indonesia.

\section{References}

Agenor, P.-R. \& da Silva, L. A. P., 2013. Inflation Targeting and Financial Stability: A Perspective from the Developing World. Banco Central do Brazil Working Papers, Volume 324.

Fleming, J. M., 1962. Domestic Financial Policies under Fixed and under Floating Exchange Rates. IMF Staff Papers, 9(3), pp. 369-380.

Juhro, S. M. (2015). The Role of the Central Bank in Promoting Sustainable Growth: Perspectives on the Impelementation Flexible ITF in Indonesia. Afro Eurasion Studies Journal, 4(1), 23-61.

Juhro, S. M. \& Goeltom, M. S., 2015. Monetary Policy Regime in Indonesia. Dalam: A. Kohsaka, penyunt. Macro-Financial Linkages in the Pacific Region. London-New York: Routledge, pp. 219-248.

Mishkin, F. S., 1999. International Experiences with Different Monetary Policy Regimes. Journal of Monetary Economics, 43(3), pp. 579-605.

Mundell, R. A., 1963. Capital Mobility and Stabilization Policy under Fixed and Flexible Exchange Rates. The Canadian Journal of Economics and Political Science, 29(4), pp. 475-485.

Warjiyo, P. \& Juhro, S. M., 2016. Kebijakan Bank Sentral: Teori dan Praktik. Jakarta: PT RajaGrafindo Persada.

Warjiyo, P. and Juhro, S.M. (2019), Central Bank Policy: Theory and Practice, Emerald Publishing Ltd., London. 
Open Access This chapter is licensed under the terms of the Creative Commons AttributionNonCommercial-NoDerivatives 4.0 International License (http://creativecommons.org/licenses/bync-nd/4.0/), which permits any noncommercial use, sharing, distribution and reproduction in any medium or format, as long as you give appropriate credit to the original author(s) and the source, provide a link to the Creative Commons license and indicate if you modified the licensed material. You do not have permission under this license to share adapted material derived from this chapter or parts of it.

The images or other third party material in this chapter are included in the chapter's Creative Commons license, unless indicated otherwise in a credit line to the material. If material is not included in the chapter's Creative Commons license and your intended use is not permitted by statutory regulation or exceeds the permitted use, you will need to obtain permission directly from the copyright holder.

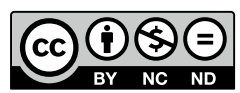

